\title{
Phytoprotection
}

\section{Effect of media and temperature on sporulation of Septoria apiicola, and of inoculum density on septoria blight severity in celery}

\author{
I.W. Mudita et A.C. Kushalappa
}

Volume 72, numéro 3, 1991

URI : https://id.erudit.org/iderudit/706009ar

DOI : https://doi.org/10.7202/706009ar

Aller au sommaire du numéro

Éditeur(s)

Société de protection des plantes du Québec (SPPQ)l

ISSN

0031-9511 (imprimé)

1710-1603 (numérique)

Découvrir la revue

Citer cet article

Mudita, I. \& Kushalappa, A. (1991). Effect of media and temperature on sporulation of Septoria apiicola, and of inoculum density on septoria blight severity in celery. Phytoprotection, 72(3), 97-103.

https://doi.org/10.7202/706009ar
Résumé de l'article

Nous avons étudié la production de conidies du Septoria apiicola sur sept milieux géloses à $20^{\circ} \mathrm{C}$. Après 12 jours d'incubation, la production de conidies fut abondante sur les géloses d'infusion de feuilles de céleri seules (CA) ou additionnées de pomme de terre dextrosee (CPDA). En général, les géloses contenant des extraits de la plante hôte, incluant le jus V-8 (CVA), ont produit davantage de conidies que les autres géloses. Le nombre de conidies par boîte et la surface des colonies ont augmenté au fur et à mesure que la température augmentait jusqu'à un maximum puis a diminué rapidement. Un polynôme du deuxième degré a expliqué $99 \%$ de la variation du nombre de conidies par boîte. La température optimale prédite par le modèle fut de $22,4^{\circ} \mathrm{C}$. Un modèle BETE linéarisé a expliqué $98 \%$ de la variation de la surface des colonies. La température optimale prédite par le modèle fut de $22,7^{\circ} \mathrm{C}$. La gravité de l'infection sur des feuilles de céleri (Apium graveolens var. dulce) a augmenté au fur et à mesure que la concentration de l'inoculum augmentait. Un polynôme du deuxième degré a expliqué $92 \%$ de la variation du nombre de lésions par feuilles pour des concentrations de 5-140 conidies $/ \mathrm{cm}^{2}$ de feuille. Néanmoins, les prévisions du modèle furent moins fiables pour des concentrations inférieures à 17 conidies $/ \mathrm{cm}^{2}$ de feuille.
Ce document est protégé par la loi sur le droit d'auteur. L'utilisation des services d’Érudit (y compris la reproduction) est assujettie à sa politique d'utilisation que vous pouvez consulter en ligne.

https://apropos.erudit.org/fr/usagers/politique-dutilisation/ 


\title{
Effect of media and temperature on sporulation of Septoria apiicola, and of inoculum density on septoria blight severity in celery
}

\author{
I. W. Mudita and A.C. Kushalappa \\ Department of Plant Science, Macdonald Campus of McGill University, \\ 21111 Lakeshore Rd., Sainte-Anne-de-Bellevue, Québec, Canada H9X 1 C0
}

(Received 1991-05-07; accepted 1991-09-23)

\begin{abstract}
The number of conidia produced by Septoria apiicola was quantified on seven media incubated at $20^{\circ} \mathrm{C}$. Conidia were produced abundantly on celery agar (CA) and celery potato dextrose agar (CPDA) after 12 days of incubation. In general, media containing celery decoction, including cleared V8 juice agar (CVA), produced more conidia than those without celery decoction. The number of conidia and the colony area produced per plate on CA increased with increase in temperature up to an optimum temperature and then decreased markedly. A second-order linear regression equation explained $99 \%$ of the variation in the number of conidia produced on CA plates incubated at temperatures ranging from 15 to $30^{\circ} \mathrm{C}$, with the predicted optimum temperature of $22.4^{\circ} \mathrm{C}$. Ninety eight percent of the variations in the colony area were explained by a linearized BETE-equation with the predicted optimal temperature of $22.7^{\circ} \mathrm{C}$. Blight severity in celery (Apium graveolens var. dulce) increased with increase in inoculum density. For inoculum density ranging from 5-140 conidia/ $\mathrm{cm}^{2}$ of leaf surface, $92 \%$ of the variations in the number of lesions per leaf, pooled from two experiments, were explained by a second-order linear regression equation. The model was less reliable for inoculum densities less than 17 conidia/ $\mathrm{cm}^{2}$ of leaf surface.
\end{abstract}

Mudita, I.W., and A.C. Kushalappa. 1991. Effect of media and temperature on sporulation of Septoria apiicola, and of inoculum density on septoria blight severity in celery. PHYTOPROTECTION 72: 97-103.

Nous avons étudié la production de conidies du Septoria apiicola sur sept milieux gélosés à $20^{\circ} \mathrm{C}$. Après 12 jours d'incubation, la production de conidies fut abondante sur les géloses d'infusion de feuilles de céleri seules (CA) ou additionnées de pomme de terre dex trosée (CPDA). En général, les géloses contenant des ex traits de la plante hôte, incluant le jus V-8 (CVA), ont produit davantage de conidies que les autres géloses. Le nombre de conidies par boîte et la surface des colonies ont augmenté au fur et à mesure que la température augmentait jusqu'à un maximum puis a diminué rapidement. Un polynôme du deuxième degré a expliqué $99 \%$ de la variation du nombre de conidies par boîte. La température optimale prédite par le modèle fut de $22,4^{\circ} \mathrm{C}$. Un modèle BETE linéarisé a expliqué $98 \%$ de la variation de la surface des colonies. La température optimale prédite par le modèle fut de $22,7^{\circ} \mathrm{C}$. La gravité de l'infection sur des feuilles de céleri (Apium graveolens var. dulce) a augmenté au fur et à mesure que la concentration de l'inoculum augmentait. Un polynôme du deuxième degré a expliqué $92 \%$ de la variation du nombre de lésions par feuilles pour des concentrations de 5-140 conidies $/ \mathrm{cm}^{2}$ de feuille. Néanmoins, les prévisions du modèle furent moins fiables pour des concentrations inférieures à 17 conidies $/ \mathrm{cm}^{2}$ de feuille.

\section{Introduction}

Celery [Apium graveolens L. var. dulce (Mill.) Pers.] is an economically important vegetable crop in Québec. Grown mainly in the muck-soil region of the province, it was valued at $\$ 5.4$ million for a total production area of 406 ha in 1989 (Statistics Canada 1990). Septoria blight, induced by Septoria apiicola Speg., threatens the crop in years of abundant rainfall or where overhead sprinkler irrigation is used, conditions that provide long durations of wetness required for infection (Berger 1970). The pathogen produces chlorotic spots on leaf laminae and later on petioles. The lesions enlarge rapidly and turn necrotic (Dixon 1981). When the disease is severe, the entire crop may be lost (Sherf and MacNab 1986). To reduce this risk, early and frequent fungicide applications are recommended to manage the disease (CPVQ

$\overline{0031-9511 / 91} \$ 1.00+.10$
1987), but an efficient management strategy is not presently available. In order to develop a more efficient and environmentally sound management practice for septoria blight, better understanding of the various biological aspects of the pathogen and the disease is necessary.

The information available on factors influencing the production of conidia of S. apiicola is scarce. Sheridan (1968) produced conidia on potato dextrose agar but Wolcan (1987) obtained abundant conidia using Fries modified agar and V8 juice agar. Similarly, the relationship between inoculum density and blight severity is also not clearly understood. Berger (1970) reported that the number of lesions produced by $S$. apiicola increased with increase in inoculum concentration but at very high inoculum concentrations the number of lesions was reduced. More information on production of conidia of S. apiicola and the effect of inoculum density on blight severity is re- 
quired to study specific environmental factors critical for blight development.

The objectives of this study were to select a suitable medium and temperature level for inoculum production, and to model the effect of inoculum density on the number of lesions produced by S. apiicola.

\section{Materials and methods}

Production of inoculum. S. apiicola was isolated from a diseased celery plant collected from a commercial field in Sainte-Clotilde, Québec, in 1989. The isolate was used to inoculate plants grown in the greenhouse from which one diseased leaf was selected for further isolation. The leaf was cut into discs and the discs were surface disinfected by immersing in $1 \% \mathrm{NaOCl}$ for $2 \mathrm{~min}$. After being rinsed, the discs were suspended in sterile water for 10-15 min to release the conidia. The suspension of conidia was diluted to approximately 1000 conidia/mL and $5 \mathrm{~mL}$ of the suspension was dispersed on water-agar medium in a Petri plate. Following overnight incubation at $20^{\circ} \mathrm{C}$, one germinating conidium was transferred into each of five plates of celery-agar medium and incubated at $20^{\circ} \mathrm{C}$ and a $16-\mathrm{h}$ photoperiod in a growth chamber (Forma Scientific Model 3740 ) for 12 days. Only the conidia cultured in this medium were used in all the experiments, with no subsequent sub-culturing.

Inoculum for all experiments was obtained by flooding 12-day-old cultures with $2 \mathrm{~mL}$ sterile distilled water. After 10-15 min, the resulting suspensions of conidia were filtered through two layers of sterile muslin cloth and the concentration of the suspensions was determined using a hemacytometer.

Preparation of media. Media tested were potato dextrose agar (PDA), potato dextrose peptone agar (PDPA), cleared V8 juice agar (CVA), celery agar (CA), celery dextrose agar (CDA), celery peptone agar (CPA), and celery potato dextrose agar (CPDA). PDA and CVA were prepared as recommended by Tuite (1969) and PDPA by following the method of Louis and Cooke (1985). CA was prepared by adding $320 \mathrm{~mL}$ of celery decoction into $680 \mathrm{~mL}$ of water containing $12 \mathrm{~g}$ bacto-agar (Difco). Celery decoction was prepared from $50 \mathrm{~g}$ of shredded celery leaves steamed in $500 \mathrm{~mL}$ distilled water for $1 \mathrm{~h}$. CDA and CPA were prepared by adding $5 \mathrm{~g}$ dextrose and $2.5 \mathrm{~g}$ peptone, respec- tively, into $250 \mathrm{~mL}$ CA. CPDA was prepared from CA by replacing bacto-agar with dehydrated bacto-PDA (Difco). All media were autoclaved for $20 \mathrm{~min}$ at $100 \mathrm{kPa}$ and then were adjusted to a pH of 5.0 with $25 \%$ lactic acid.

Inoculation, incubation and quantification of conidia. Five $10-\mu \mathrm{L}$ droplets of conidium suspension were dispensed onto each plate (100mm x $15 \mathrm{~mm}$ ) using a digital micropipette (Eppendorf). Inoculum concentrations used for media and temperature experiments were 200000 and 150000 conidia/mL, respectively. For the media experiment, plates were incubated at $20^{\circ} \mathrm{C}$ in the growth chamber (Forma Scientific Model 3740) for 12 and 18 days whereas for the temperature experiment, plates were incubated at $15^{\circ}, 20^{\circ}, 25^{\circ}$ and $30^{\circ} \mathrm{C}$ for 12 days. Two 15-W cool black fluorescent tubes positioned at $0.3 \mathrm{~m}$ above the cultures provided the lighting for a photoperiod of $16 \mathrm{~h}$. There were four and three replicates for the media and the temperature experiment, respectively.

After incubation, $15 \mathrm{~mL}$ of $1 \%$ formaldehyde with $0.01 \%$ Tween- 80 in sterile distilled water was poured into each plate. Fifteen minutes later, the resulting suspension of conidia was then filtered using two layers of muslin cloth. The number of conidia in each suspension was counted, four counts per suspension, with the aid of a hemacytometer. The shape of the conidia was also noted. Colony diameter was measured at five random directions per colony and the colony area was calculated based on the average value.

Preparation and inoculation of plants. Transplants of celery cv. Florida 683 were produced by placing one seed on the surface of each cell of a seedling tray previously filled with Profi-Mix B type VPW 30 (a mixture of peat moss, dolominitic lime stone, perlite, and vermiculite) and then lightly covered with a layer of fine sand. The seedling tray was then placed in a growth chamber (Conviron Model E15) adjusted to a $22^{\circ} \mathrm{C}$ day $/ 18^{\circ} \mathrm{C}$ night temperature and a 14-h photoperiod. Aftersix weeks, seedlings were transplanted into plastic pots (12-cm deep, 12-cm upper-internal diameter) filled with a mixture of $2 / 3$ part $(\mathrm{v} / \mathrm{v})$ soil containing $20 \%$ organic matter, $1 / 6$ part peat, and $1 / 6$ part perlite. Potted plants were maintained in a growth chamber and were watered daily. A 15-15-18 fertilizer (Plant-Prod) prepared at $0.3 \mathrm{~g} / \mathrm{L}$ was applied daily along with the 
irrigation water. $\mathrm{CaCO}_{3}$ was applied twice a week at $8 \mathrm{~g} / \mathrm{L}$ to prevent black-heart disease.

At the sixth-leaf stage, three fully expanded leaves per plant were tagged for blight monitoring. Plants were inoculated using an automatic spray chamber (Incom Int.). The canopy level was placed at $1.3 \mathrm{~m}$ below the solid-cone-type spray nozzle which moved horizontally. Prior to spraying each suspension, at a constant pressure of $172 \mathrm{kPa}$, the speed of nozzle movement was adjusted to deposit 140, 70, 35.5, 17.5, 8.8, and 4.4 conidia $/ \mathrm{cm}^{2}$ from inoculum suspensions of $80000,40000,20000,10000,5000$, and 2500 , respectively. The density of deposition of conidia was determined by placing three water-agar plates $(100 \mathrm{~mm} \times 15 \mathrm{~mm})$ at the canopy level and the counts were made on four $1-\mathrm{cm}^{2}$ circles per plate. The actual number of conidia deposited from each suspension was 140.04, 69.98, 35.02, 17.51, 8.76, and 4.80, respectively. After spraying the inoculum, each plant was enclosed in a transparent plastic bag and placed in the growth chamber (Incom Int.) maintained at $20^{\circ} \mathrm{C}$ for $72 \mathrm{~h}$. The bags were then removed and the plants were transferred into the greenhouse and arranged according to a randomized complete block design on a bench. Lesions were counted daily on the three-tagged leaves after their first appearance until they began to coalesce. The experiment was conducted twice.

Data analyses. Analysis of variance was performed on the number of conidia and the colony area from the media experiment. The Duncan's new multiple range test was used to separate treatment means. Regression analysis was used to model the effect of temperature on the number of conidia and on the colony area and the effect of inoculum density on the number of lesions. A second model considered appropriate for the temperature experiment is the BETE-function (Analytis 1977). The linearized form of this function was fitted to the proportion of maximum number of conidia and to the proportion of maximum colony area. For the number of lesions, the analysis was carried out on the data from the individual experiment and also on the pooled data. All analyses were conducted using SAS/STAT ${ }^{\mathrm{TM}}$ software for IBM-PC (SAS Institute Inc. 1987).

\section{Results}

Effect of media on sporulation. Conidia were produced most abundantly on $\mathrm{CA}$ and on CPDA after 12 days of incubation at $20^{\circ} \mathrm{C}$ (Table 1). In general, media containing celery decoction produced more conidia than those without celery decoction. Two exceptions were noted, CDA after 12 days of incubation and CPA after 18 days of incubation. Dextrose or peptone combined with celery decoction enhanced colony development. Large colony area on CPDA after 12 days of incubation was followed by marked increase in the production of conidia after 18 days of incubation. Marked increase in the number of conidia was also observed on CVA, CDA, and CPA.

Differences in shape were observed among conidia produced on different media. Conidia produced on PDA and PDPA were slightly

Table 1. Effect of various media on number of conidia and colony area of S. apiicola at $20^{\circ} \mathrm{C}$

\begin{tabular}{lcccc}
\hline Media $^{\S}$ & \multicolumn{2}{c}{ Number of conidia per plate $\left(\mathrm{x} 10^{6}\right)^{\dagger}$} & & \multicolumn{2}{c}{ Colony area $\left(\mathrm{mm}^{2}\right)^{\dagger}$} \\
\cline { 2 - 4 } & 12 days & 18 days & 12 days & 18 days \\
\hline CA & $5.44 \mathrm{a}$ & $7.00 \mathrm{a}$ & $91 \mathrm{a}$ & $123 \mathrm{ac}$ \\
CPDA & $5.39 \mathrm{a}$ & $7.03 \mathrm{a}$ & $135 \mathrm{~b}$ & $146 \mathrm{~b}$ \\
CPA & $5.03 \mathrm{~b}$ & $6.30 \mathrm{~b}$ & $122 \mathrm{c}$ & $147 \mathrm{~b}$ \\
CVA & $2.74 \mathrm{c}$ & $7.00 \mathrm{a}$ & $76 \mathrm{~d}$ & $128 \mathrm{a}$ \\
PDA & $0.81 \mathrm{~d}$ & $1.16 \mathrm{~d}$ & $86 \mathrm{ad}$ & $109 \mathrm{c}$ \\
PDPA & $0.52 \mathrm{~d}$ & $1.27 \mathrm{~d}$ & $87 \mathrm{ad}$ & $121 \mathrm{ac}$ \\
CDA & $0.51 \mathrm{~d}$ & $2.32 \mathrm{c}$ & $112 \mathrm{c}$ & $117 \mathrm{c}$ \\
\hline
\end{tabular}

$\S \mathrm{CA}=$ celery agar; $\mathrm{CPDA}=$ celery potato dextrose agar; $\mathrm{CPA}=$ celery peptone agar; $\mathrm{CVA}=$ cleared $\mathrm{V} 8$ juice agar; $\mathrm{PDA}=$ potato dextrose agar; $\mathrm{PDPA}=$ potato dextrose peptone agar; $\mathrm{CDA}=$ celery dextrose agar.

$\div$ Average of four replicates. Numbers in a column followed by the same letter are not significantly different $(P>0.05)$ according to the Duncan's new multiple range test. 
atypical while those produced on other media were similar to those found in lesions.

Effect of temperature on sporulation. The number of conidia produced per plate increased with increase in temperature up to a maximum level and then decreased markedly (Fig. 1A). Colony area also followed the same pattern (Fig. 1B). A second-degree linear polynomial regression equation explained significantly
$(P \leq 0.01)$ the effects of temperature on the number of conidia per plate (Eq. 1):

CONIDIA $=-48.06+4.84 T-0.11 T^{2}$, $R^{2}=0.99$

where CONIDIA is the predicted number of conidia produced per plate $\left(\times 10^{6}\right)$ and $T$ is the temperature $\left({ }^{\circ} \mathrm{C}\right)$. The optimum temperature for
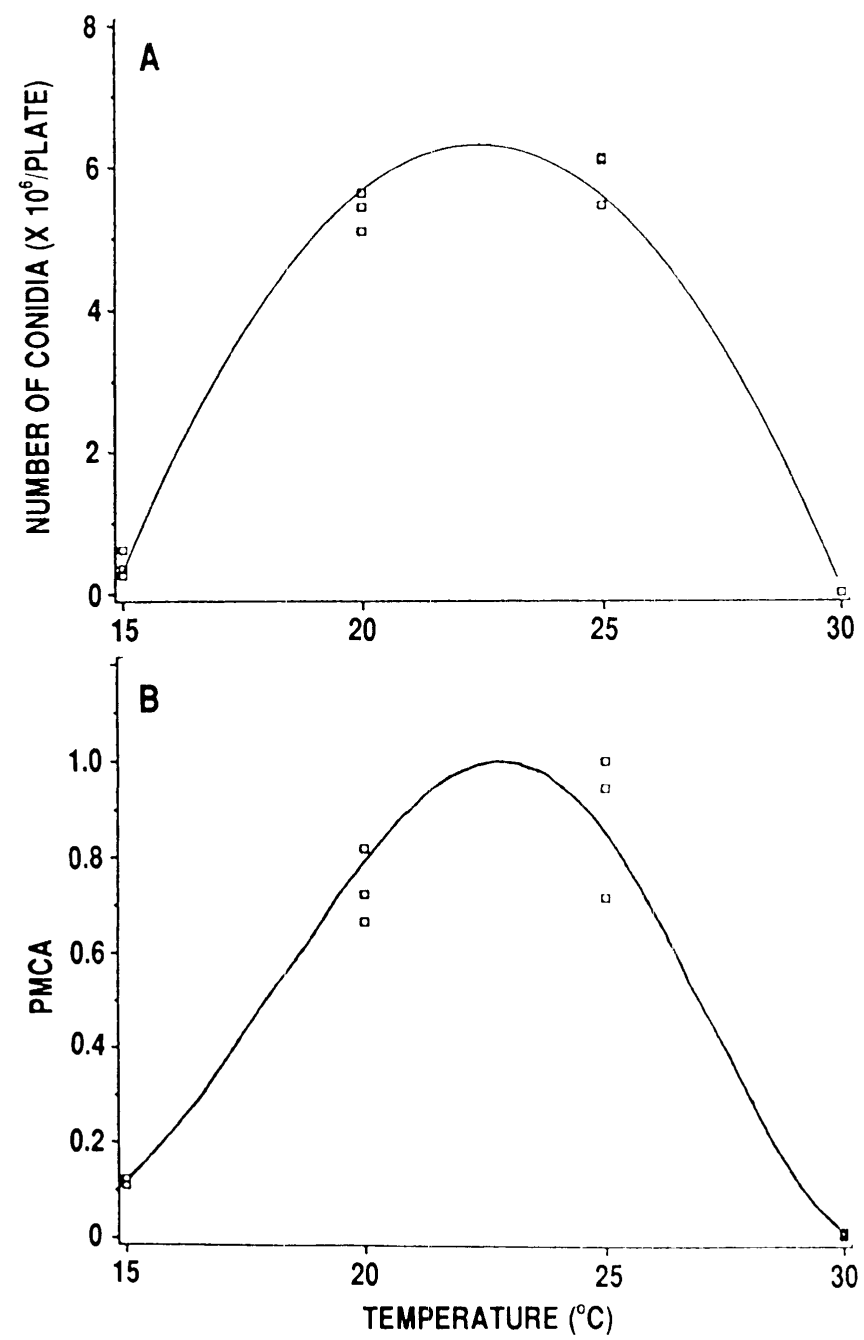

Figure 1. Effect of temperature $(T)$ on A) number of conidia $\left(x 10^{6}\right)$ and $\mathbf{B})$ colony area $\left(\mathrm{mm}^{2}\right)$. The equation to predict production of conidia is CONIDIA $=-48.06+4.84 T-0.11 T^{2}$, $R^{2}=0.99$ and the equation to predict colony development is $P M C A=\exp \left(3.58+3.29 \ln T^{\prime}+2.16 \ln \left[1-T^{\prime}\right]\right), R^{2}=0.98$ where CONIDIA is the predicted number of conidia per plate, $P M C A$ is the proportion of maximum colony area (colony area in $\left.\mathrm{mm}^{2}\right), T$ is the temperature, $T^{\prime}$ is $\left(T-T_{\min }\right)$ / $\left(T_{\max }-T_{\min }\right)$, and $R^{2}$ is the coefficient of determination. 
production of conidia predicted using Eq. 1 was $22.4^{\circ} \mathrm{C}$. For the colony area, the polynomial model underestimated the colony area at $25^{\circ} \mathrm{C}$ since the overall responses were skewed to the lower temperatures. A good fit to the proportion of maximum colony area was obtained from use of the linearized BETE-function. The back- transformed BETE-equation for the proportion of the maximum colony area (the observed maximum $=1.97 \times 10^{2} \mathrm{~mm}^{2}$ ) is:

$$
\begin{aligned}
P M C A= & \exp \left(3.58+3.29 \ln T^{\prime}\right. \\
& \left.+2.16 \ln \left[1-T^{\prime}\right]\right),
\end{aligned}
$$
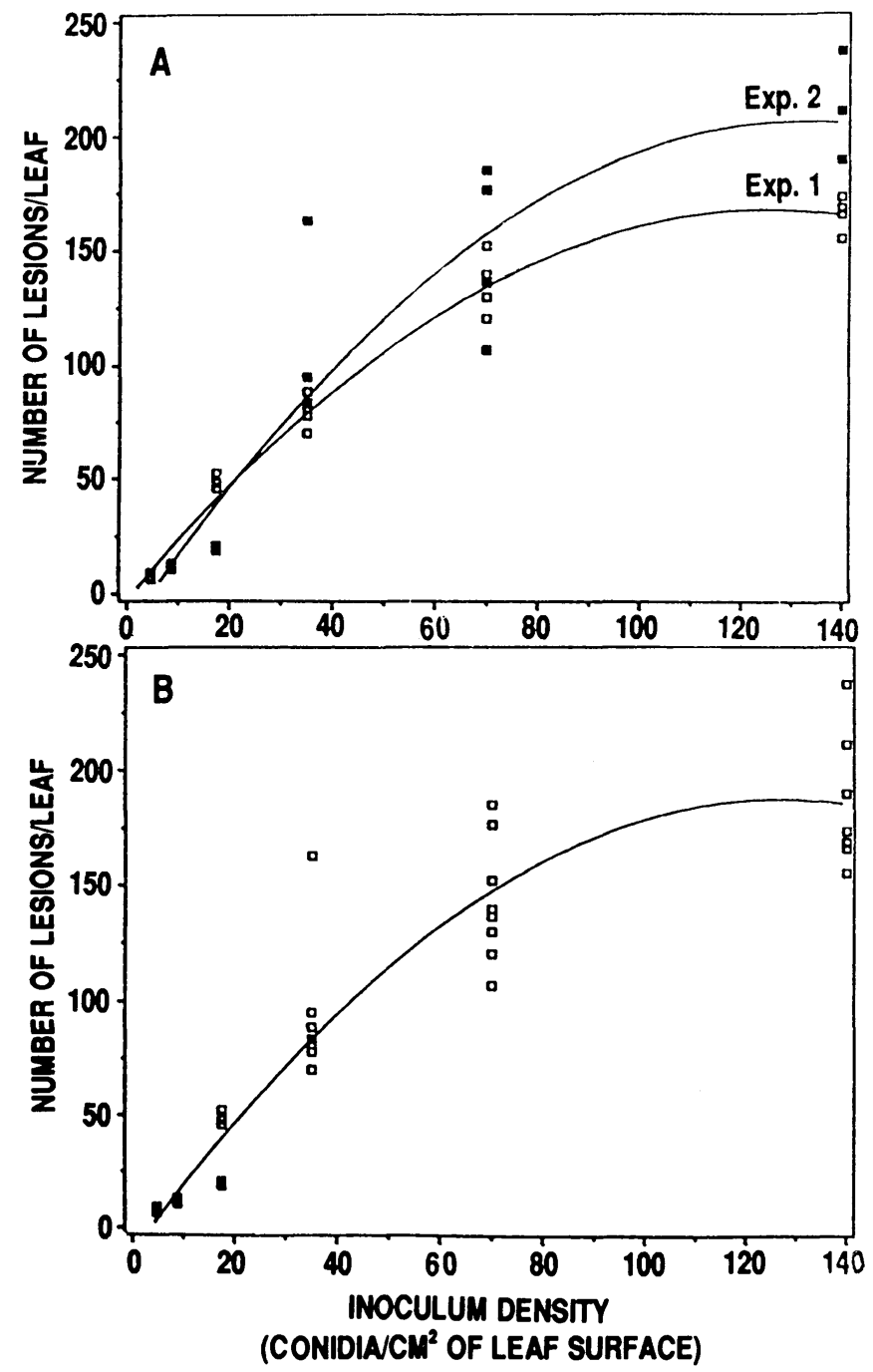

Figure 2. Effect of inoculum density on disease severity induced by S. apiicola for A) experiment 1 and experiment 2 and $\mathbf{B}$ ) pooled data. Equations to predict number of lesions are: $N L E S_{1}=6.02+2.89 I N O D E N-0.01 I_{N O D E N^{2}, R^{2}=0.98}$ $N L E S_{2}=-15.79+3.35 I N O D E N-0.01 I N O D E N^{2}, R^{2}=0.91$; and

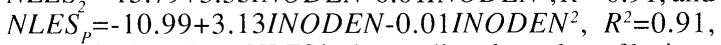
respectively, where $N L E S$ is the predicted number of lesions per leaf, subscripts 1,2 , and $P$ indicate the number of experiment and pooled data, respectively, INODEN is the inoculum density (conidia/ $\mathrm{cm}^{2}$ of leaf surface), and $R^{2}$ is the coefficient of determination. 
where $P M C A$ is the predicted proportion of maximum colony area (colony area in $\mathrm{mm}^{2}$ ) and $T^{\prime}=\left(T-T_{\text {min }}\right) /\left(T_{\text {max }}-T_{\text {min }}\right)$ in which $T$ is the temperature ( $\left.{ }^{\circ} \mathrm{C}\right)$ and subscripts min and max indicate the minimum and the maximum temperature for activity, respectively. $T_{\text {min }}$ and $T_{\text {max }}$ were selected iteratively until the highest coefficient of determination $\left(R^{2}\right)$ was obtained. Equation 2 was obtained at the $T_{\text {min }}$ and $T_{\text {max }}$ value of 11.0 and $30.5^{\circ} \mathrm{C}$, respectively. Based on this equation, the predicted optimum temperature for colony development was $22.78^{\circ} \mathrm{C}$.

Effect of inoculum densities on disease severity. Lesions were large and non-coalescing on plants inoculated with 4.8 conidia $/ \mathrm{cm}^{2}$ and were small and readily coalesced on plants inoculated with 70 and 140 conidia/ $\mathrm{cm}^{2}$. Although the lesions tended to appear earlier on older leaves, the final number of lesions depended more on the leaf size than on the leaf position. The maximum number of lesions was observed 18 days after inoculation and this maximum was used for further analyses. The number of lesions increased with the increase in inoculum density (Fig. 2). Second-degree linear regression equations explained significantly $(P \leq 0.01)$ the variation in the number of lesions from the individual experiment. Since the $F$-test carried out to examine the homogeneity of experimental error from both experiments indicated no significant difference $(P>0.01)$, a regression model was also fitted to the pooled data. Equations to predict the number of lesions based on the data from experiment 1 , experiment 2 , and pooled data are:

$$
\begin{aligned}
& \text { NLES }_{l}=-6.02+2.89 \text { INODEN }^{-0.01 \text { INODEN }^{2},} \\
& R^{2}=0.98
\end{aligned}
$$

$$
\begin{aligned}
& \text { NLES }_{2}=-15.79+3.35 \text { INODEN } \\
& \quad-0.01 \text { INODEN }^{2}, \\
& R^{2}=0.91
\end{aligned}
$$

$$
\begin{aligned}
& N L E S_{P}=-10.99+3.13 \text { INODEN } \\
& -0.01 \text { INODEN }^{2} \text {, } \\
& R^{2}=0.91
\end{aligned}
$$

where NLES is the predicted number of lesions per leaf, subscripts $I, 2$ and $P$ indicate experiment 1 , experiment 2 , and the pooled data, respectively, and INODEN is the inoculum density (conidia $/ \mathrm{cm}^{2}$ ). Models based on data from individual experiments and pooled data accounted for up to $91 \%$ of the variation in the number of lesions observed. The model based on experiment 1 had a higher coefficient of determination $\left(R^{2}\right)$ and a lower mean square error (MSE) but a less desirable pattern of residuals as compared to the model based on experiment 2 or to that based on pooled data. Models based on data from individual experiments gave poorer predictions than that based on pooled data at the lower inoculum densities. All models had negative intercepts which were not significantly different from zero $(P>0.01)$.

\section{Discussion}

Production of sufficient amount of inoculum is a primary concern for quantitative epidemiological studies of many diseases including septoria blight. Abundant conidia were obtained when celery decoction was added into media. The magnitude of the increment, however, was influenced by the basal medium used. When celery decoction was added into media containing dextrose or peptone, more conidia were produced after 18 days than after 12 days of incubation. Larger colony area as a result of addition of peptone or dextrose to media containing celery decoction accounted for more sporulation.

CA and CPIDA readily produced abundant conidia, but preparation of these media required a supply of celery leaves. When celery leaves are not readily available, however, CVA which contains celery could be considered as an alternative. Wolcan (1987) reported that V8 juice agar was one of the best media for production of secondary conidia of S. apiicola. Here, CVA provided abundant conidia but significantly less than those produced on CA, CPDA, and CPA after 12 days.

Media not containing celery decoction produced slightly atypical conidia. The shape of conidia varied more in conidia produced on media containing no celery decoction than in those produced on media containing celery decoction. However, according to Gabrielson and Grogan (1964) this variation was common in S. apiicola and was not likely attributed to a particular isolate.

Temperature may have affected sporulation directly by influencing production of conidia or indirectly by influencing colony development which later provided a larger colony area for further production of conidia. As a result, both 
production of conidia and colony area had similar response curves. However, the optimum temperature for the development of colonies was closer to the maximum than that for the production of conidia. Consequently, use of second-order polynomial to model the effect of temperature on the colony area appeared inadequate. The linearized BETE-functions gave a better fit to the colony area. For fitting BETEfunctions to the colony area, $T_{\min }$ and $T_{\text {max }}$ were selected merely based on the coefficients of determination. Experimental proof of $T_{\min }$ and $T_{\text {max }}$ would improve the model.

The variations in the pooled number of lesions per leaf obtained from different inoculum densities were explained by a second-order linear regression equation with a non-significant negative intercept. The equation implied that, within the range of inoculum densities tested, the ratio of disease to inoculum decreased with the increase in inoculum density and that the minimum inoculum threshold for the pathogen was not critical. A decrease in the ratio of disease to inoculum may occur when there is competition among conidia for susceptible infection sites (Van der Plank 1975).

The model based on the pooled data was less reliable for inoculum densities lower than $\mathbf{1 7 . 5}$ conidia/ $\mathrm{cm}^{2}$. Densities above 70 conidia $/ \mathrm{cm}^{2}$ resulted in more crowded and easily coalesced lesions, making reading more difficult. Therefore, for quantitative studies involving plant inoculations and lesion counting, an inoculum density from $17-35$ conidia/ $/ \mathrm{cm}^{2}$ of leaf surface is considered the most appropriate.
This research was funded by the Conseil des recherches en pêche et agroalimentaire du Québec. The scholarship provided by the government of Indonesia to the first author is gratefully acknowledged. We thank O. Carisse for French translation of the abstract and Dr. T.C. Paulitz for his useful suggestions.

Analytis, S. 1977. Über die Relation zwischen biologischer Enkwicklung un Temperatur bei phytopathogenen Pilzen. Phytopathol. Z. 90: 64-76.

Berger, R.D. 1970. Epiphytology of celery late blight. Proc. Fla. State Hortic. Soc. 83: 208-212.

CPVQ (Conseil des productions végétales du Québec). 1987. Légumes protection 1983-1984. Agdex 250/605. Ministère de l'Agriculture, des Pêcheries et de l'Alimentation du Québec. 86 pp.

Dixon, G.R. 1981. Vegetable crop diseases. Macmillan Publ., London. 404 pp.

Gabrielson, R.L., and R.G. Grogan. 1964. The celery late blight organism Septoria apiicola. Phytopathology 54: 1251-1257.

Louis, I., and R. C. Cooke. 1985. Conidial matrix and spore germination in some plant pathogens. Trans. Br. Mycol. Soc. 84: 661-667.

SAS Institute Inc. 1987. SAS/STAT Guide for personal computers. Version 6 edition. SAS Institute Inc., Cary, NC. 1028 pp.

Sherf, A.F., and A.A. MacNab. 1986. Vegetable diseases and their control. 2nd ed. John Wiley \& Sons, New York. 728 pp.

Sheridan, J.E. 1968. Condition for germination of pycnidiospores of Septoria apiicola Speg. N.Z. J. Bot. 6: 315-322.

Statistic Canada. 1990. Fruit and vegetable production. Catalogue 22-0033 Seasonal. Ministry of Supply and Service Canada, Ottawa. 29 pp.

Tuite, J. 1969. Plant pathological methods, fungi and bacteria. Burgess Publ., Minneapolis, MN. 239 pp.

Van der Plank, J.E. 1975. Principles of plant infection. Academic Press, New York. 216 pp.

Wolcan, S. 1987. Conidios secundarios de Septoria apiicola Speg. I. Comparación con las picnidiosporas. Medios de cultivo que estimulan la producción de los dos tipos de esporas. Turrialba 37: 239-244. 